This item was submitted to Loughborough's Research Repository by the author.

Items in Figshare are protected by copyright, with all rights reserved, unless otherwise indicated.

\title{
Some thoughts on storytelling, science and dealing with a post-truth world
}

PLEASE CITE THE PUBLISHED VERSION

https://doi.org/10.13110/storselfsoci.13.1.0120

PUBLISHER

Wayne State University Press

VERSION

AM (Accepted Manuscript)

\section{PUBLISHER STATEMENT}

This work is made available according to the conditions of the Creative Commons Attribution-NonCommercialNoDerivatives 4.0 International (CC BY-NC-ND 4.0) licence. Full details of this licence are available at: https://creativecommons.org/licenses/by-nc-nd/4.0/

\section{LICENCE}

CC BY-NC-ND 4.0

\section{REPOSITORY RECORD}

Wilson, Michael. 2019. "Some Thoughts on Storytelling, Science and Dealing with a Post-truth World". figshare. https://hdl.handle.net/2134/32129. 


\section{Some Thoughts on Storytelling, Science and Dealing with a Post-Truth}

\section{World ${ }^{1}$}

Michael Wilson

Loughborough University

I would like to start with a confession of sorts: I tweet. I am not a particularly avid user of twitter - certainly less so than some other people - and I never tweet late at night or in the wee hours (like some people do). In fact, most of my tweets are retweets. End of confession - but that explains why, when I first sat down at my desk in on $2^{\text {nd }}$ January this year (2017), in that period between the end of the seasonal festivities and restart of teaching at the university, to think about what I might make the subject of today's talk, I was distracted by my twitter feed as I was delivered the daily satirical cartoon from the New Yorker magazine (I am one of the New Yorker's 7.69 million followers).

The cartoon in question depicts an old man wearing a sash with '2016' emblazoned on it, addressing an infant, sporting a top hat and a '2017' sash, as he emerges from the public bathroom. The caption reads, "I'd give it a few minutes, kid."

\footnotetext{
1 This is a slightly amended transcript of a closing keynote, delivered to the International Conference on Storytelling for Health in Swansea, UK, on 17 June 2017. As such, the tone of the oral nature of the presentation has been preserved and amendments have been limited to issues of clarity, often as a result of the post-talk discussion with conference delegates.
} 


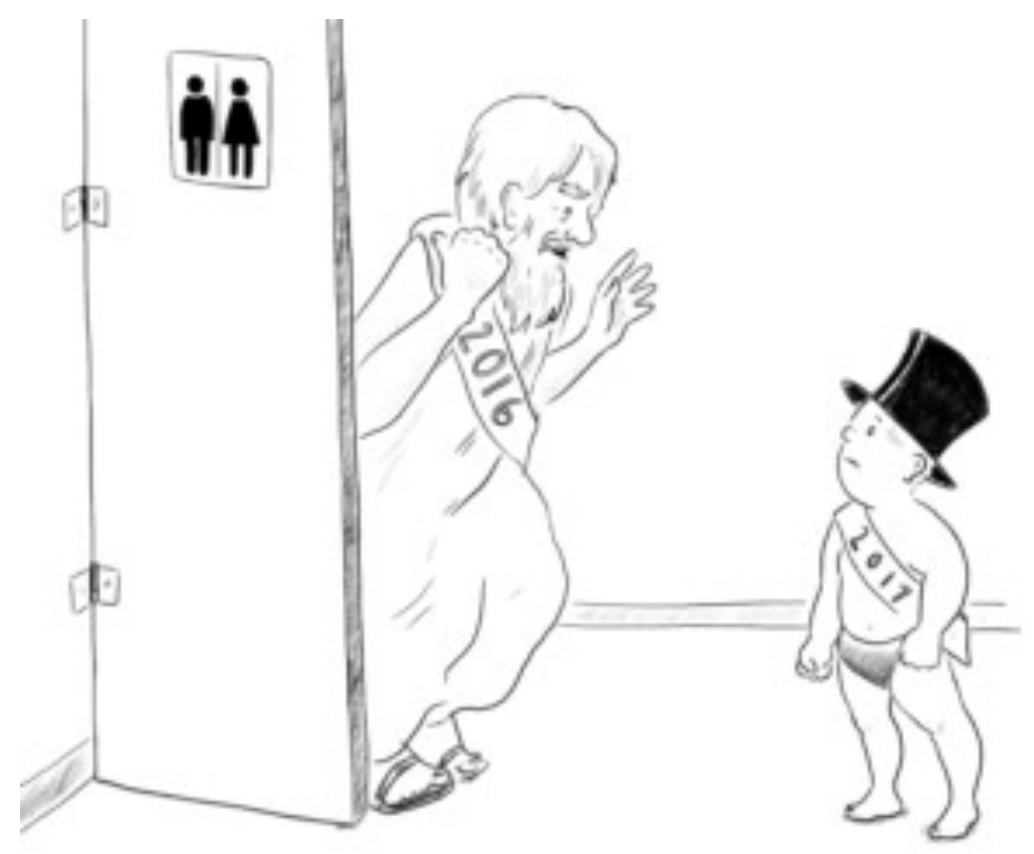

"I'd give it a few minutes, kid."

I offer you this simply by way of explaining my personal state of mind as I began to think about some of the issues I'd like to make the subject of this paper. This absolutely summed up my feelings about 2016, a stinker of a year, whose residual odour was likely to remain pungent for some time to come. Suffice it to say, as we entered 2017 I was not in the most positive of states of mind.

A few weeks later, having mulled over a few things in my mind, I came across another piece of news, namely that the Oxford Dictionaries had named 'posttruth' as the word of the year for 2016. 'Post-truth', defined as an adjective 'relating to or denoting circumstances in which objective facts are less influential in shaping public opinion than appeals to emotion and personal belief'. I shall take issue with this particular definition later, but their justification for the awarding of the accolade to 'post-truth' was this: whilst the word had been in use with its current meaning pertaining to the irrelevance of truth, since 1992, when 
the writer Steve Tesich used it in an article in The Nation, 2016 had seen a very significant increase in the use of the word, with spikes occurring specifically around the time of the EU Referendum in the UK and the Presidential Election in the United States.

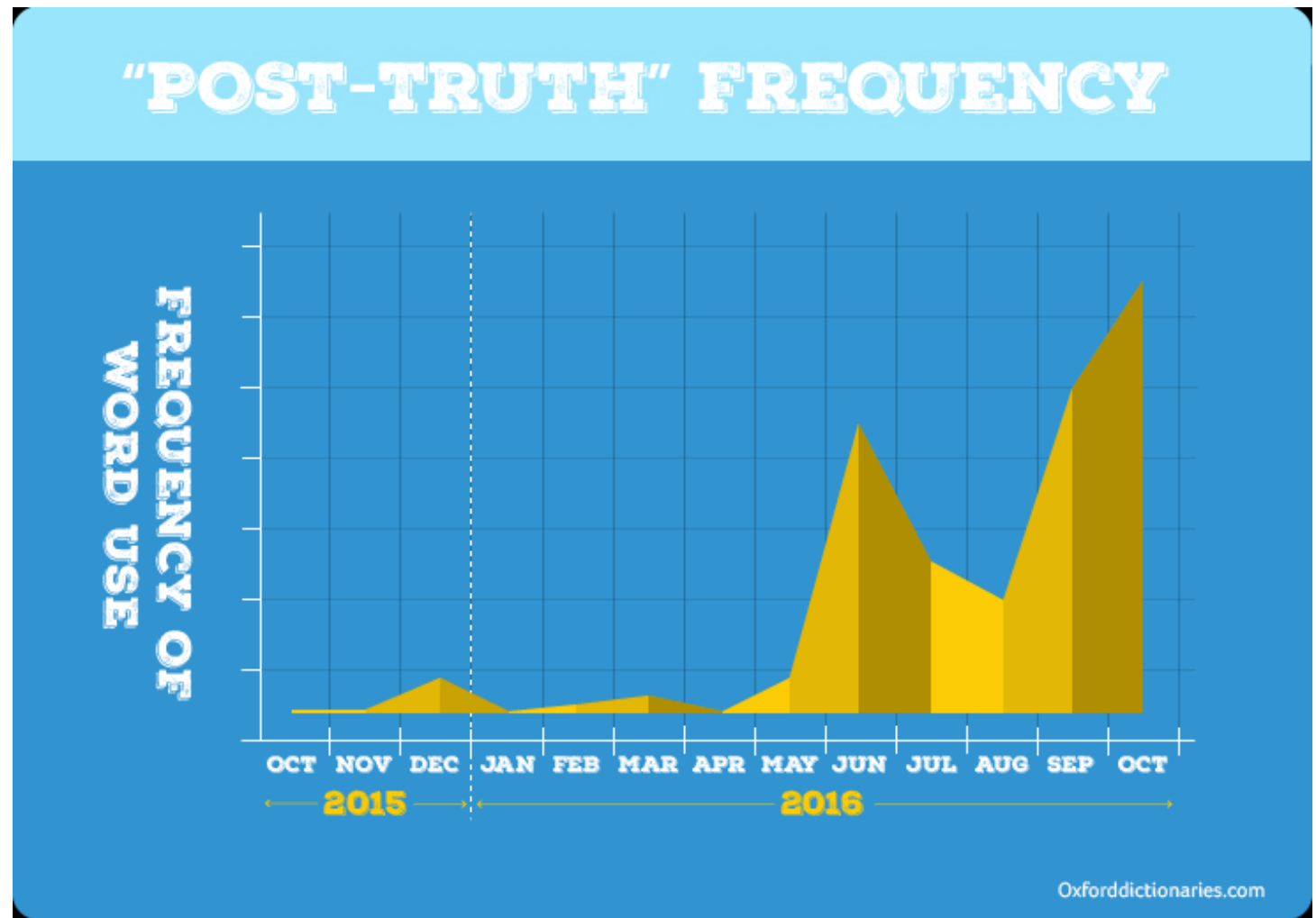

This seemed to me to be significant. Not only had this post-truth world delivered us into dangerously uncertain political times, but it had also raised for me some very challenging professional questions concerning my role as a researcher in storytelling, working with other researchers from a range of science disciplines, including in the area of health and well-being, and as an advocate for an increased role for storytelling in public life and policy-making. It is, therefore, how the role, value and potential of storytelling within the public sphere more 
broadly, and the healthcare domain more specifically, might be better understood in a post-truth context, that I would like to reflect on today.

So, when I finally sat down to try and write some meat onto the bones of my thoughts about this, I had on my desk in front of me four 'texts', all of which deal with the matter of truth and stories in one way or another and which I hoped I could triangulate ${ }^{2}$ between in order to start addressing some of the questions I had made for myself. The first of these happens to be another cartoon from the New Yorker, this one being from $1^{\text {st }}$ September 2016, more than two months before the US Presidential Election, but already a time when (according to the graph), 'post-truth' as a concept was gathering traction towards its peak around election day.

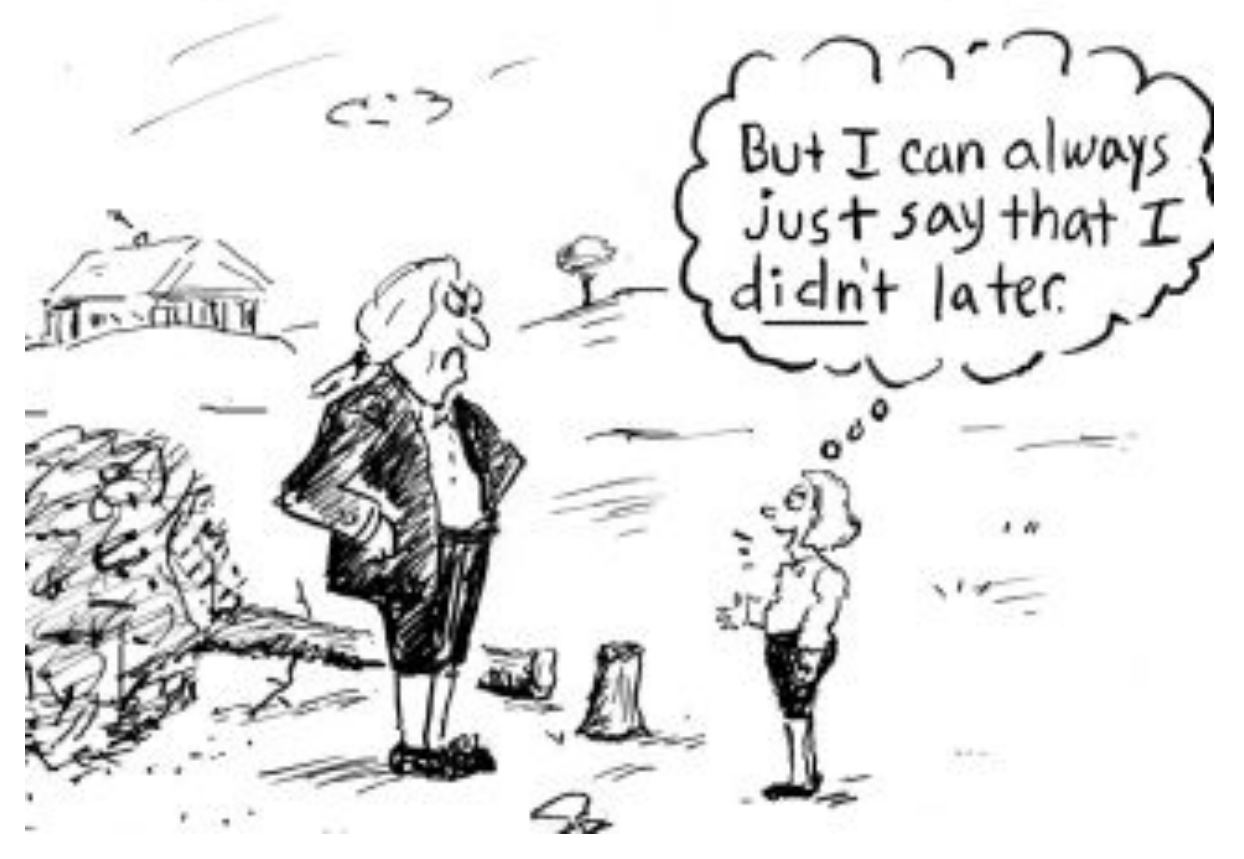

"I cannot tell a lie - I did cut it down..."

2 I'm not sure if one can triangulate between four texts. Perhaps 'quadrangulate' is the word I'm looking for? 
This cartoon depicts a young boy speaking to a stern-looking man, whose hands are placed on his hips in order to emphasize his obvious displeasure at the child. Both are dressed in the style of the late eighteenth century and in the background lies a felled tree. The caption reads, "I cannot tell a lie - I did cut it down...". At the same time, a thought bubble emerges from the child's head that reads, "But I can always just say that I didn't later."

I am sure that nobody really needs the cartoon explaining to them. It is a representation of one of the most enduring pieces of American national mythology and the most famous story about George Washington, the first president. As a six-year old child, George has chopped down a cherry tree in the family garden. When confronted by his angry father he immediately owns up to his misdeed, seemingly incapable of dishonesty. His father forgives him, claiming that his son's honesty is worth more than a thousand trees.

It is a story not only about the virtue of honesty, but it also places truth-telling at the very core of the American national character - honesty becomes a patriotic obligation. The cartoon cleverly questions the validity of the myth in a society where claims made one day can be contradicted the next, without consequence, and where bare-faced lies and audacious untruths can been brazenly peddled, and even when found out, can simply be repeated more loudly and more brazenly than before, as if the more a lie is repeated, the more true it becomes. 
The second text is an abstract from the late John Berger's 2004 essay entitled 'Ten Dispatches About Endurance in Face of Walls'. It is a remarkable, short essay and it seemed particularly appropriate to return to it in the light of Trump's election and his campaign promises concerning the US-Mexican border. In dispatch number five, he talks specifically about the power of storytelling. I do not wish to dwell on all of it, but it is nonetheless quite short, so please indulge me if I share with you the whole dispatch.

The secret of storytelling amongst the poor is the conviction that stories are told so that they may be listened to elsewhere, where somebody, or perhaps a legion of people, know better than the storyteller or the story's protagonists, what life means. The powerful can't tell stories: boasts are the opposite of stories, and any story however mild has to be fearless and the powerful today live nervously.

A story refers life to an alternative and more final judge who is far away. Maybe the judge is located in the future, or in the past that is still attentive, or maybe somewhere over the hill, where the day's luck has changed (the poor have to refer often to bad or good luck) so that the last have become first.

Story-time (the time within a story) is not linear. The living and the dead meet as listeners and judges within this time, and the greater the number of listeners felt to be there, the more intimate the story becomes to each listener. Stories are one way of sharing the belief that justice is imminent. And for such a belief, children, women and men will fight at a given moment with astounding ferocity. This is why tyrants fear storytelling: all stories somehow refer to the story of their fall. (95-96)

I find this a very reassuring text as it portrays storytelling as an overwhelmingly positive force. For Berger storytelling has an unquenchable democratic energy, consistently championing the underdog, speaking truth to power and portraying the realities of a world blighted by social injustice. This is storytelling as an unstoppable act of resistance and, as the postcard pinned to the wall above my 
desk in my study tells me, quoting the words of the Black American poet and essayist James Baldwin, "the duty of the artist is to resist." It is storytelling as understood by Karl Kroeber, the American literary scholar, who in his book, Retelling/Rereading: the Fate of Storytelling in Modern Times, claims that “Genuine Storytelling is inherently antiauthoritarian" (4), because stories are told and received by individuals, not groups, and therefore each telling or listening is its own 'unauthorized' version of the truth.

The third text is from the eminent storytelling scholar Jack Zipes and it is an essay entitled 'How Storytellers Can Change Education in Changing Times: Stealing from the Rich to Build Community Bridges' and can be found in his 2004 book Speaking Out: Storytelling and Creative Drama for Children. Whilst Zipes is attracted to the idea of the subversive storyteller, he also admits that storytelling can be used for more nefarious purposes. Using the folkloric figure of 'the good thief', he describes the two types of storyteller thus:

The difference between the good thief and the bad crook is that the good thief admits that we are all obliged to rob in some way and somehow wants to offset injustices and repay his or her crime by helping the disadvantaged and maintaining a subversive tradition of human compassion and responsibility, whereas the bad crook refuses to admit his or her involvement and culpability and continually seeks ways to deceive the majority of people (...) [H] e or she uses the forces of the mass media, government, and courts to gain more of a stranglehold over the minds and lives of common people. (38)

Like Zipes, I am attracted to the idea of storytelling as being inherently a good thing, but must reluctantly admit that it is not always so and what I am hoping to argue today is that we, who champion the value of storytelling (in health or any other context) must be courageous enough to adopt a more critical approach to 
our own practice, to be sceptical, if necessary, and, in doing so, reassert its

validity where it's due. The arrival of the 'post-truth' age demands that we do no less, as we are more in need of storytelling than ever, as long as it is of the kind that is done by honest thieves.

The fourth and final text is a story called 'The Story of the Fairy Tale' by the nineteenth century Danish writer Carl Ewald. It was, incidentally, used by Jack

Zipes to open his keynote address to the inaugural annual symposium of The George Ewart Evans Centre for Storytelling in 2007, and is published as 'Storytelling as Spectacle in a Globalized World' in his 2009 book Relentless Progress. It is one of a number of stories that deal with the issue of truth and the way that story acts as a different way of understanding the world.

Once upon a time, ever so many years ago, Truth suddenly vanished from out of the world.

When people perceived this, they were greatly alarmed and at once sent five wise men in search of Truth. They set out, one in this direction and one in that, all plentifully equipped with travelling expenses and good intentions. They sought for ten long years. Then they returned, each separately. While still at a distance, they waved their hats and shouted that they had found Truth.

The first stepped forward and declared that truth was Science. He was not able to finish his report, however, for before he had done, another thrust him aside and shouted that that was a lie, that Truth was Theology and that he had found it. Now while these two were at loggerheads - for the Science man replied to the attack vigorously - there came a third and said, in beautiful words, that Love was Truth without a doubt. Then came the fourth and stated, quite curtly, that he had Truth in his pocket, that it was Gold, that all the rest was childish nonsense. At last came the fifth. He could not stand on his legs, gave a gurgling laugh, and said that Truth was Wine. He had found Truth in Wine, after looking everywhere.

Then the five wise men began to fight, and they pummeled one another so lustily that it was horrible to see. Science had its head broken, and Love was so greatly ill-treated that it had to change its clothes before it could show itself in respectable society. Gold was so thoroughly stripped of every covering that people felt awkward about knowing it; and when the bottle broke, Wine flowed away into the mud. But Theology came off worst of all: 
everybody had a blow at it and it received such a basting that it became the laughingstock of all beholders.

And people took sides, some with this one and some with that, and they shouted so loud that they could neither see nor hear for the din. But far away, at the extreme end of the earth, sat a few and mourned because they thought that Truth had gone to pieces and would never be made whole again.

Now, as they sat there, a little girl came running up and said that she had found Truth. If they would just come with her - it was not very far - Truth was sitting in the midst of the world, in a green meadow.

Then there came a pause in the fighting, for the little girl looked so very sweet. First one went with her; then another; and ever more... At last, they were all in the meadow and there discovered a figure the like of which they had never seen before. There was no distinguishing whether it was a man or a woman, an adult or a child. Its forehead was pure as that of one who knows no sin; its eyes deep and serious as those of one who has read into the heart of the whole world. Its mouth opened with the brightest smile and then quivered with a sadness greater than any could describe. Its hand was soft as a mother's and strong as the hand of a king; its foot trod the earth firmly, yet crushed not a flower. And then the figure had large, soft wings, like the birds that fly at night.

Now as they stood there and stared, the figure drew itself erect and cried, in a voice that sounded like bells ringing:

"I am Truth!"

"It's a Fairy Tale!" said Science.

"It's a Fairy Tale!" cried Theology and Love and Gold and Wine.

Then the five wise men and their followers went away, and they continued to fight until the world was shaken to its centre. But a few old and weary men and a few young men with ardent and eager souls and many women and thousands of children with great wide eyes: these remained in the meadow where the Fairy Tale was.

(Ewald in Zipes (ed.), Spells of Enchantment: The Wondrous Fairy Tales of Western Culture, 1991, 564-65)

So, let me put those texts momentarily on one side and tell you my story. I have been thinking about storytelling, in one way or another, as a performer, as a $\mathrm{PhD}$ student, as a teacher and as a researcher for more than thirty years. For the past decade or so, I have been particularly involved in inter-disciplinary projects, using storytelling with colleagues from the science-based disciplines, such as health and environmental sciences, to address issues of policy and social justice. As an arts and humanities researcher, entering these spaces has not always been 
easy - we speak different languages, we have different research traditions, different paradigms. We even have different ideas of what constitutes research in the first place. We have heard about some of these challenges from a number of researchers and practitioners alike at the conference this weekend. But these have also been some of the most enriching interactions that I've had during my professional career. And this has also been reflected in some of the comments we have heard this weekend. Indeed this conference stands as a testament to the rich possibilities of interdisciplinary discourse.

The basis of this work for me is this. At our very core we humans are storytelling animals or homo narrator, as Joseph Gold would have it (23), or homo fictus, as proposed by Jonathan Gottschall (xiv). We tell stories, amongst other reasons, to make sense of our thoughts and experiences, our interactions with the environment and each other, to formulate our beliefs, our identities and our values. And then to communicate all of this to our fellow human beings. And then, as our fellow humans in turn communicate their stories to us, and we become listeners, as well as tellers of tales, we reformulate and retell our own stories with fresh nuance and new understanding in the light of those stories heard. And so the cycle continues. This is storytelling as a process, as a way of thinking about the world, as a tool for navigating our personal and collective journeys.

Back in 2010 I was invited to Wits University in Johannesburg to participate in a series of discussions about the development of storytelling within the South African higher education system. What I witnessed were long, intense debates as 
to what a university ought to look like in the post-Apartheid age: was the Western model of the University, inherited through colonialism, the only model, let alone the right model? Was there such a thing as a distinctive African university that reflected African ways of observing and understanding the world, whilst maintaining its reputation on the global university stage? There was much talk about indigenous knowledge systems, a term I had only vaguely heard prior to my visit, and it was as an indigenous knowledge system that storytelling was understood as having an important role to play in the Academy.

It was an inspiring week in Johannesburg and I went away thinking not only of storytelling as a way of thinking, but also as a way of knowing the world, as a knowledge system, and by that I mean not as a set of fixed opinions and sentiments, but as a way of producing knowledge, new insights and fresh understanding.

At that time I was already involved in a number of inter-disciplinary research projects and was just about to start work on a large project looking at the way that storytelling might be used to increase the levels and depth of engagement in the public debate around climate change. This involved a number of conversations with senior civil servants at the Department of Energy and Climate Change in Whitehall, discussing the way that policy was formulated and implemented and the challenges they were facing in engaging large sections of the public through their traditional consultation and focus group approaches. Armed with my experiences in Johannesburg, I began to realize that whilst storytelling was largely absent from the public discourse on climate change, 
there were other knowledge systems that were at play and often competing with each other: scientific knowledge systems; technical knowledge systems; bureaucratic knowledge systems. Each of these knowledge systems had their own way of knowing and understanding the world and how it works and, moreover, I realized, they operated on a hierarchical basis. The hierarchy was determined by the context of a particular discussion. For example, if the discussion was about the modeling of future weather events, it was the scientific knowledge that stood atop the hierarchy. If it was about the roll out of renewable energy infrastructure, it was technical knowledge that had the upper hand. And if it was a discussion about policy implementation or the design of initiatives to encourage behaviour change, it was bureaucratic knowledge that was most dominant. In fact, it was all a bit like the five wise men in Ewald's tale, each one convinced of its own veracity and superiority, only coming together in common cause when it was to ridicule the idea that story, a fairy tale no less, might be taken seriously as a legitimate source of knowledge and wisdom.

Of course, the situation is more variable and complex than that and I am greatly simplifying things in order to make my point, but that point is that storytelling, a narrative knowledge system, is rarely even incorporated into those discussions and certainly is never at the top of the knowledge hierarchy. Narrative knowledge is often dismissed as 'anecdotal', even if it is professional testimony, or its value is seen merely in the form of a vehicle for the more effective communication of other kinds of knowledge. It is rarely acknowledged that storytelling might contribute (or aid in the production of) new knowledge, in its own right. Instead we have storytelling in the service of science, if at all. 
This has always seemed to me to be problematic for a number of reasons. First, the kinds of knowledge that dominate these debates are always what we might call 'expert knowledges'. There are often very good reasons for this. For example, the discussion around climate change is often dominated by climate change science and that science is very complex and difficult and still evolving. Likewise, debates within healthcare are often dominated by medical knowledge and at times we probably wouldn't want it any other way. And, let me make it clear, I am in no way arguing against any knowledge systems, but merely that understanding can be enriched by the inclusion of storytelling. The challenge with 'expert knowledges' is that they are also 'professional knowledges' and, as such, they have the purpose of simultaneously including and excluding. They seek to communicate advanced knowledge and complex concepts, but they also use language that is specialized and obscure, that is designed to assert the superior status of the speaker and to keep out those who have not been inducted into the closed circles of the profession and do not have access to that language. Such exclusion is not always intentional, but it happens, and academics are often the worst culprits. In terms of climate change it is hardly surprising that many do not engage in the public debate because they do not have the language that would enable them to participate. Likewise, how many of us have not felt somewhat intimidated by medical language that we don't fully understand, when discussing our health with our GP?

About five years ago I went to the doctor with a small, painless, squishy lump in the middle of my chest, only to have it diagnosed as a harmless lipoma. I'd never 
heard the word before, so I went home and googled it. Unfortunately, by the time I got home I had forgotten the unfamiliar word and instead typed a similar word I did know into the search engine: lymphoma. I spent an anxious hour before further searches revealed my mistake.

By contrast, and notwithstanding the discussions we've had this weekend about the new 'expertise' of the patient and the fact that we are all experts of our own lives, the language of storytelling is not an 'expert' or 'professional' language in quite the same way. Admittedly, some folks are more expert than others at storytelling and there are some who tell stories professionally, but we all tell stories and, when we do, we use structures and language available and familiar to us and our audiences. That is how storytelling works; it is a universal form of communication that demands that each story is constructed in lay language that is understood by its intended audience. It seeks to include - both tellers and listeners. This means that it has the potential to bring new, previously unheard voices to the table and with it new experiences and new perspectives and new expertise. As Paschen and Ison say, “The use of expert or lay languages can exclude or include communication actors and thus influence the kind of knowledge produced and accepted as authoritative" (1084). I am minded of Dan Yashinsky's point this morning in his keynote address about the need to bring the language of story into an arena that is dominated by the sound of medical data. But it is exactly that which also makes it dangerous, because it may challenge and contradict prevailing wisdom and authority and expertise, following the Berger model of subverting existing power structures or the Kroeber model of saying what is 'unauthorized'. 
The value of storytelling, however, also lies in the kind of knowing and thinking that it brings. Professional/expert knowledge does, by its very nature, seek to give us certainty and clarity, even if it cannot always offer reassurance. We often turn to our experts to provide us with absolute, incontrovertible truth and no more is that the case than in the area of healthcare. And yet we are often asking the impossible. As Bertrand Russell famously said in his short essay from 1933 'The Triumph of Stupidity', a critique of the rise of fascism in Germany, "The fundamental cause of the trouble is that in the modern world the stupid are cocksure while the intelligent are full of doubt" (203). The fact that the world (and arguably our times in particular) are uncertain, ever-changing and seemingly full of contradictory and multiple truths means that the very certainty for which we crave is so often unattainable and experts (at least the wise ones) will be the last people in a position to offer it.

In his 2004 book After Method: Mess in Social Science Research, the sociologist John Law describes a more complex view of the world than one drawn along the binary lines of true/false; right/wrong; fact/fiction and argues that social scientists have for too long attempted to operate in a binary world, "properly (...) understood as a set of fairly specific, determinate, and more or less identifiable processes" (5), rather than embracing the complexity of the postmodern condition, characterised by uncertainty, instability and complexity.

No doubt some things in the world can indeed be made clear and definite. Income distributions, global $\mathrm{CO}_{2}$ emissions, the boundaries of nation states, 
and terms of trade, these are the kinds of provisionally stable realities that social and natural science deal with more or less effectively. But alongside such phenomena the world is also textured in quite different ways.

On the one hand, Law acknowledges that there are some certainties, or "bankable guarantees" (9) in the world: the sun rising in the morning and setting in the evening might be one of them. There are other probabilities that are so probable that it makes practical sense to treat them as certainties: if you fall one hundred feet, you will almost certainly be killed (although there are plenty of stories that tell of people surviving much greater falls, of course). But there are many things (especially when it comes to interactions that involve human beings) that are uncertain and cannot be served through a binary approach to the world. This is what Law calls 'mess' and it is a permanent state of the world we live in. In other words, the one thing we can be certain about is the world's uncertainty.

If much of the world is vague, diffuse or unspecific, slippery, emotional, ephemeral, elusive or indistinct, changes like a kaleidoscope, or doesn't really have much of a pattern at all, then where does this leave social science?

(2)

There is no universal reality. Realities are not secure but instead they have to be practised. And the world is not passive, waiting to be seen by people. (15)

And this is where storytelling has a critical role to play. For storytelling has evolved not just as a vehicle for us to convey our experiences, but as a tool for processing information. It is a space for testing ideas, beliefs, morals, a space for 
arguing, debating and, ultimately, for discriminating between truth and lies. Stories are uniquely suited for dealing with mess - not the fruitless task of tidying it up, but helping us navigate our way through it - because stories themselves are inherently messy. They are unstable (they change from telling to telling and teller to teller); they may be unreliable (they conceal as much as they reveal); they are self-contradictory (they often raise more questions than answers). Stories are shape-shifters and tricksters, presenting wisdom as folly and folly as wisdom. But, I would argue, it is this very messiness, this ability to embrace mess as a natural state, that makes storytelling the best tool we have to deal with a messy world. Storytelling can't do everything. Perhaps it can't do most things. But it does some things really well. In his 2015 Douglas Adams Memorial Lecture at the Royal Geographical Society, the author Neil Gaiman spoke of a conversation he had once had with Adams about the threat to books from new digital platforms. Adams said, "Books are really good at being books and no matter what happens books will survive" (Alison Flood, The Guardian, 4 March 2015). Likewise, stories are designed to do the things that stories do best. We will always have the need for multiple ways of thinking about the world and knowing the world and the more ways we have, the better it will be for us. To do without any kind of knowledge (be that scientific, technical, bureaucratic, cultural, social, historical or narrative) is ultimately to impoverish our dealings with the world and with each other.

For the past ten years or so, then, my mission as a researcher has been to progress this kind of thinking about the value of narrative knowledge. I have entered any number of inter-disciplinary partnerships with the aim of promoting 
the idea of the interaction between storytelling and other knowledge systems and to try things out, hopefully on the way discovering things that work and things that don't. And this has led me to often having to adopt the position of promoting (and sometimes) defending storytelling against the suspicions of some colleagues, especially when the stories seem to challenge existing orthodoxies and power structures.

For example, when working on a small pilot study with Professor Alan Bleakley of the Peninsula Medical School and Karen Lewis of StoryWorks, exploring how storytelling might help support notions of mutual recovery within mental healthcare, we set up secure online spaces where healthcare professionals (in this case psychiatrists and general practitioners), service users/patients and carers could anonymously share their stories amongst each other. I shan't go in to the detail of that work here, but let me share one thing with you. On a number of occasions I read the anonymous stories and mistook stories that were being told by healthcare professionals to be stories of service users, and vice versa. The psychiatrists and GPs would often tell stories of vulnerability, personal challenge and mental health episodes, whilst the service users told stories of resilience and resourcefulness. It not only challenged my own prejudices and preconceptions, but it also gave a hint of how, once the permission to tell a story is granted, it can begin to fundamentally subvert and shift existing power relationships. These highly qualified, highly able healthcare professionals were telling stories that they had previously not had permission to tell, in case it compromised their professional standing. Many reported a sense of liberation in being able to recover stories that had previously remained buried. 
Nevertheless, the arrival of the post-truth world has led me to question whether, in the need to champion storytelling and its place within arenas habitually dominated by other kinds of knowledge, and particularly storytelling that might challenge conventional wisdoms, I may have been guilty of being too easy on storytelling, of neglecting our collective duty to be our own harshest critics and inquisitors? Have I prioritised the desire to have any stories told and heard over the responsibility to challenge stories that harbour dishonesty? Have I been complacent about the value of storytelling? I have regularly argued with colleagues that they may produce all the statistical data in the world, but people behave according to the stories they carry with them, not according to graphs and tables produced by academic researchers, and that that is one reason why we need to embrace storytelling. As Barry Lopez says:

We tend to believe (...) that if you can get a group of people together at a table and explain how atmospheric chemistry is creating global climate change, that people will, as we say, see the light. In their personal lives and in their career lives they will do whatever they can to effect a change. But that doesn't happen.

(Tyderman, 130)

In terms of climate change there is nothing to gain by not acknowledging the narratives of climate change deniers. That is not to agree with those narratives, but neither is it not to acknowledge their existence because no amount of data that will effect mass behavioural change on the kind of scale that is urgently needed, as long as the sceptics and deniers are telling better stories. ${ }^{3}$

\footnotetext{
${ }^{3}$ In the discussion following this presentation, one delegate quite rightly pointed out that it may not be that the sceptics and deniers simply have better stories,
} 
But 'post-truth'-ism is in danger of getting storytelling a bad name. If we are not careful storytelling will be in danger of becoming equated with anti-science, antiknowledge, anti-truth, as if to promote the idea of multiple truths, or truth as a construct, is the same as challenging scientific truth per se; as if by suggesting that everyone is an expert in their own lives, we are anti-expert - in the Govian sense $^{4}$. If we are not careful we may find ourselves on the wrong protest march.

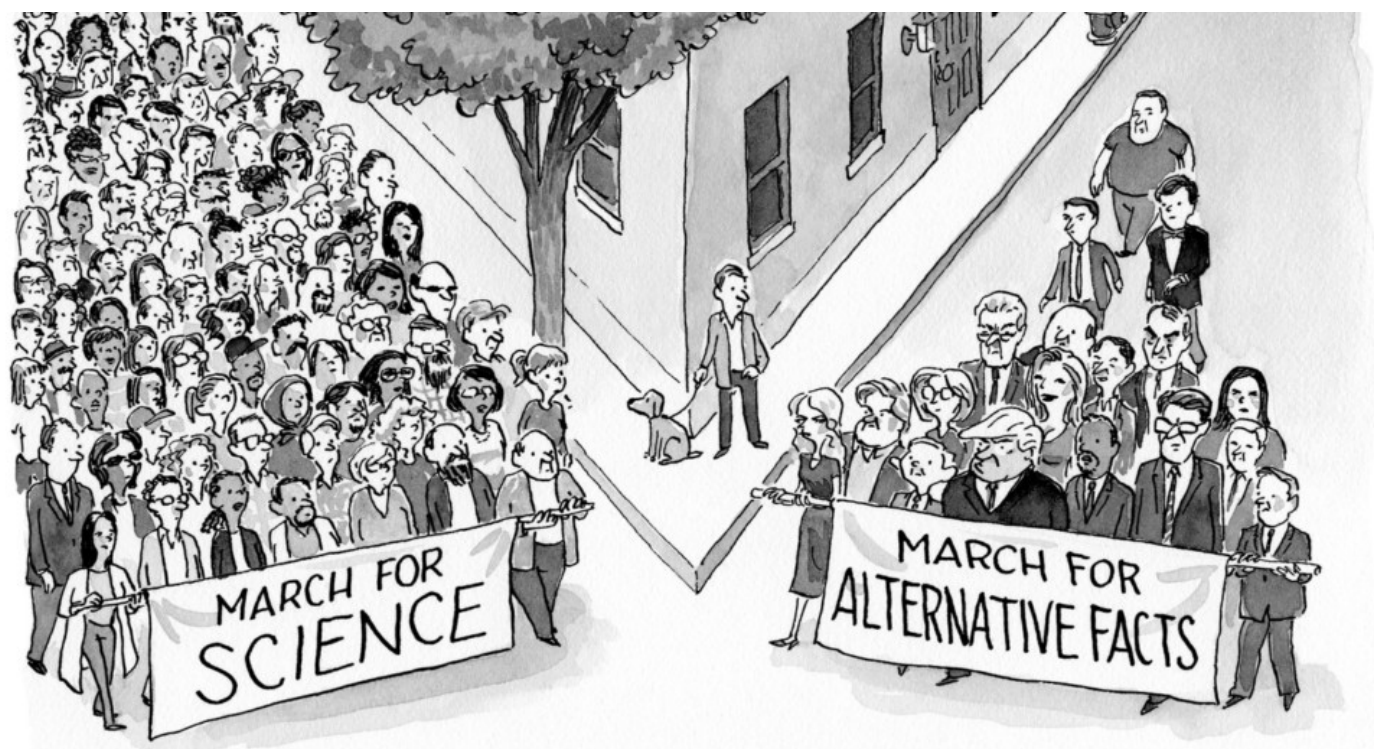

(New Yorker, 21 April 2017)

We are being given a challenge to step up our game and I, for one, am happy to accept that challenge. But at the same time, I still reject the idea of the promotion

but that they have simpler ones. This is an important point well-made and it led to a discussion around whether we have a decreasing capacity and tolerance to deal with the long-form and that which is difficult, and the importance of storytelling in that. Such a discussion is, unfortunately, beyond the scope of this paper, but is important nonetheless.

${ }^{4}$ Michael Gove is a UK Conservative Government minister who, during the EU Referendum campaign, famously declared that the British public was fed up with experts. 
of one knowledge system over another and still argue that bringing together different epistemologies will lead us towards more nuanced and intelligent policymaking and service delivery, but we need to be smarter in the way that we speak about the value of story. We need to discriminate between stories as multiple 'unauthorized' versions of the truth, as described by Kroeber and stories as 'alternative facts'. One is subversive, allowing us to challenge the existing power structures and orthodoxies that serve the interests of those who already enjoy privilege, and the other is simply lies, designed to deny us the truth and the access to knowledge and power. One is honest; one is dishonest. We need to acknowledge that storytelling is not in and of itself always a good thing and be prepared to call out the liars and the stories they tell, by telling a better story, by becoming like Zipes's honest thieves.

Storytelling must reassert itself not as a simple vehicle for scientific or medical truth, but not standing in opposition to it either. Writing in the 'Preface' to the 1805 edition of Lyrical Ballads, William Wordsworth described a more symbiotic relationship between Art and Science, whereby Art enriches scientific knowledge and allows itself to be enriched in turn:

If the labours of the men of science should ever create any material revolution, direct or indirect, in our condition and in the impressions which we habitually receive, the poet will sleep then no more than at present, but he will be ready to follow in the steps of the man of science, not only in those general indirect effects, but he will be at his side, carrying sensations into the midst of the objects of the science itself. (35-36) 
And this is where I stand with Wordsworth and take issue with the Oxford definition of 'post-truth'. This is not about objective truth versus emotional truth, or science versus storytelling. That is not the battle being fought here. It is about truth versus lies and how different kinds of truth might work together to challenge falsehoods.

So, whilst the notion of the post-truth world is a dangerous place for storytelling, ironically we need smart storytelling more than ever. Thankfully I am encouraged by the many instances of smart storytelling that we've witnessed at the conference this weekend. As the world becomes more uncertain and even messier, we need stories to help us safely and intelligently navigate our course and ensure that truth ultimately prevails. But that requires honesty from us, as storytellers, as to its limitations, as well as its values and to be constantly vigilant and prepared to criticize and question everything we do.

Wordsworth was, in his own way, imagining the interplay of different knowledge systems, a place where a belief in poetry (or story) does not suggest a disbelief in science, or vice versa, but allows us to appreciate that the world is constructed and knowledge is produced in different ways. Yes, the stakes have got higher and as storytellers we must reaffirm our old alliances, forge new ones and find common cause with those from other disciplines, including the health sciences, with whom we share the desire to improve our lot. So finally, returning to Carl Ewald's tale, let us not be blinkered followers of Science, Theology, Love, Gold or Wine. Instead I remain very definitely - and defiantly -in the verdant meadow with Truth. And I hope you do too. 


\section{Works Cited}

Berger, John 'Ten Dispatches About Endurance in Face of Walls' in Hold Everything Dear, Verso, 2016, 91-100.

Flood, Alison, 'Douglas Adams made me a writer: Neil Gaiman salutes his friend and inspiration', The Guardian, 4 March 2015.

Gold, Joseph, The Story Species: Our Life-Literature Connection, Markham, Ontario: Fitzhenry and Whiteside, 2002.

Gottschall, Jonathan, The Storytelling Animal: How Stories Make Us Human, New York: Houghton Mifflin Harcourt, 2012.

Kroeber, Karl, Retelling/Rereading: the Fate of Storytelling in Modern Times, Rutgers University Press, 1992.

Law, John, After Method: Mess in Social Science Research, Routledge, 2004.

Paschen, Jana-Axinja and Ray Ison, 'Narrative research in climate change adaptation - Exploring a complementary paradigm for research and governance', Research Policy, Vol. 43, 2014, 1083-1092.

Russell, Bertrand, 'The Triumph of Stupidity' in Mortals and Others, Routledge, 2009, 203-204.

Tyderman, William E., Conversations with Barry Lopez: Walking the Path of Imagination, University of Oklahoma Press, 2013.

Wordsworth, William and Samuel Taylor Coleridge, Lyrical Ballads 1805, edited by Derek Roper, 2nd edition, Plymouth: Macdonald and Evans, 1976 Zipes, Jack (ed.), Spells of Enchantment: The Wondrous Fairy Tales of Western Culture, Penguin, 1991. 
Zipes, Jack, 'How Storytellers Can Change Education in Changing Times: Stealing from the Rich to Build Community Bridges' in Speaking Out: Storytelling and Creative Drama for Children, New York: Routledge, 2004, 35-59

Zipes, Jack, 'Storytelling as Spectacle in a Globalized World' in Relentless Progress, New York: Routledge, 2009, 141-156. 